\title{
Introduction: The Myoepithelial Cell and Milk Letdown; Entrance to the Multifunctional Role of Oxytocin
}

\author{
Isabel A. Forsyth • Margaret C. Neville
}

Published online: 4 August 2009

(C) Springer Science + Business Media, LLC 2009

As long ago as the 1890 s, there were suggestions that stellate cells recognised on the surface of mammary alveoli in several species might have a function in moving secreted milk from alveoli to teat. However, because of inadequate histological methods, confusion subsequently developed as to whether these cells were smooth muscle or myoepithelium (reviewed in [1]). This confusion was finally resolved by K.C. Richardson in the Department of Anatomy at the University of London, who, using thick $(75-100 \mu \mathrm{m})$, silver-impregnated sections of goat mammary gland, clearly distinguished the two cell types [2] — in contracted and distended alveoli, the myoepithelial cells showed structural changes consistent with their role as the contractile tissue responding to oxytocin in milk ejection.

Keith Richardson's interest in the mammary gland seems to have resulted from a request in January 1945 from Dr (later Fellow of the Royal Society and Professor) John Folley at the National Institute for Research in Dairying, Shinfield, Reading, U.K., for assistance with histology in a study of adrenalectomy in goats. The Institute had no histologist at the time. Richardson was initially somewhat doubtful. He had become responsible for the major job of moving the Department of Anatomy, Faculty of Medical Sciences, University College, London, from its wartime home in Surrey back to its pre-war premises in Gower

\footnotetext{
I. A. Forsyth

Formerly The National Institute for Research in Dairying and The Babraham Institute,

Cambridge, UK

M. C. Neville ( $\square)$

Department of Physiology and Biophysics,

UCDenver School of Medicine,

Aurora, CO, USA

e-mail: Peggy.neville@UCDenver.edu
}

Street in a country that had still to emerge from the bombing and deprivations of the war. However, he agreed, and this led to a wider and productive collaboration and a long correspondence which dealt with more matters than science, including their mutual interest in modern art.

Richardson also developed a technique, importantly including the use of perfusion fixation, to prepare thin transverse sections of the whole mammary gland of goats [3]. Ductal and alveolar growth were revealed in new detail, enabling quantitation of alveolar area which greatly aided later studies by the Shinfield laboratory of the hormonal control of mammary growth and lactation in the goat.

In 1959, Folley's sight was very severely affected following a failed eye operation. Assisted by a reader and crucially by his wife, Mary, he continued to direct research in his Shinfield department. Studies of oxytocin and milk ejection remained one of Folley's particular interests. In 1969 he was awarded the Dale Medal, its highest honour, by the Society for Endocrinology. His medal lecture, given seamlessly from memory, reviewed the history and the current status of research on the neuroendocrine milkejection reflex [4]. Showing the breadth of his interests, the lecture ended by considering milk-ejection as treated in mythology and art.

Three years after the appearance of Richardson's article, Jim Linzell, who had been working independently on this same problem at the University of Edinburgh, published confirmation of Richardson's work, in sweat and salivary and mammary gland, and of the functional role of these rather unusual contractile cells [1], showing that the cells contracted in response to oxytoxin. Linzell carried this work further, showing the topological relation of these cells to the mammary alveolus. He also suggested that the myoepithelial cells on the ductal structures form a third layer outside the basal cell layer. However, the relation 
between basal cells and myoepithelial cells in mammary ducts has yet to be clarified [5].

Shortly after his paper was published Linzell began to use a novel technique to study milk secretion: he autotransplanted one udder to the neck of the goat where he could use the carotid artery, a fairly accessible source of blood, for studies of the relation of milk secretion to mammary perfusion [6]. He also used this preparation to show the neuroendocrine nature of the let-down reflex. Letdown could be achieved in the perfused gland with oxytocin, but not with milking as in the intact gland. However, if the intact udder was milked, let-down was achieved in the transplant. This novel experiment showed that a neural stimulus from milking, missing in the transplant, gave rise to a stimulus that must be carried through the blood, e.g. oxytocin.

The regulation of oxytocin secretion has received a great deal of attention in recent years, as summarized in a recent review by Hatton and Wang [7], as it also appears to behave as a neurotransmitter under certain circumstances. The hormone has also elicited wide interest as it appears to mediate adaptive responses of the mother to her newborn infant [8]. Another interesting line of investigation is dissection of the mechanism of oxytocin receptor signalling as reviewed in this journal in 2005 [9]. Clearly the role of oxytocin in the letdown reflex was only the tip of the iceberg.

\section{References}

1. Linzell JL. The silver staining of myoepithelial cells, particularly in the mammary gland, and their relation to the ejection of milk. J Anat. 1952;86:49-57.

2. Richardson KC. Contractile tissue in the mammary gland with special reference to the myoepithelium in the goat. Proc. R. Soc. London, Ser. B. 1949;136:30-45.

3. Richardson KC. Measurement of the total area of secretory epithelium in the lactating mammary gland of the goat. J Endocrinol. 1953;9:170-84.

4. Folley SJ. The milk-ejection reflex: a neuroendocrine theme in biology, myth and art. J Endocrinol. 1969;44:476-90.

5. Regan J, Smalley M. Prospective isolation and functional analysis of stem and differentiated cells from the mouse mammary gland. Stem Cell Rev. 2007;3:124-36.

6. Linzell JL. Transplantation of mammary glands. Nature. 1960;188:596-8.

7. Hatton GI, Wang YF. Neural mechanisms underlying the milk ejection burst and reflex. Prog Brain Res. 2008;170:155-66.

8. Neumann ID. Brain oxytocin: a key regulator of emotional and social behaviours in both females and males. J Neuroendocrinol. 2008;20:858-65.

9. Reversi A, Cassoni P, Chini B. Oxytocin receptor signaling in myoepithelial and cancer cells. J Mammary Gland Biol Neoplasia. 2005;10:221-9. 